\title{
THREE NEW SPECIES OF DENDROCHILUM (ORCHIDACEAE) AND THEIR PHYLOGENETIC POSITIONS ACCORDING TO PLASTID AND NUCLEAR RIBOSOMAL ITS SEQUENCES
}

\author{
HENRIK A. PEDERSEN ${ }^{1}$, BARBARA GRAVENDEEL ${ }^{2} \&$ DEDEN MUDIANA ${ }^{3}$
}

\begin{abstract}
SUMMARY
Three new species of the Southeast Asian orchid genus Dendrochilum Blume are described. All three seem to belong to the phenetically defined subgenus Platyclinis (Benth.) Pfitzer. As indicated by the name, D. celebesense H.A. Pedersen \& Gravend. originates from Sulawesi. The geographic origins of D. coccineum H.A. Pedersen \& Gravend. and D. warrenii H.A. Pedersen \& Gravend., on the other hand, are unknown, but parsimony analyses of sequences of the plastid accD-psaI intergenic spacer and nuclear ribosomal ITS1-5.8S-ITS2 region and morphological affinities suggest they should both be counted as members of the Philippine flora.
\end{abstract}

Key words: Dendrochilum, accD-psaI, nrITS, Philippines, Sulawesi, phylogeny, taxonomy.

\section{INTRODUCTION}

In the latest complete survey of the Southeast Asian orchid genus Dendrochilum (Pedersen et al., 1997) 271 species were recognized. However, even after subsequent regional treatments covering the main diversity centres of this genus - viz. the Philippines (Pedersen, 1997a), Sumatra (Comber, 2001), and Borneo (Wood, 2001) - new species keep popping up (e.g., Pedersen, 1997b, 2001). In this paper, three further species are being added, which were all brought into cultivation for the first time over the past two years and of which only cultivated collections are known without precise locality data.

Morphologically, these three new species seem to belong to subgenus Platyclinis (Benth.) Pfitzer because of their synanthous inflorescences, column with apical wing or hood and entire, flat rostellum (Pedersen et al., 1997). To check whether molecular characters could be used to infer the geographic origin of the new species described here, DNA sequences were obtained from the plastid accD-psaI intergenic spacer and nuclear ribosomal ITS1-5.8S-ITS2 region. These regions were used in previous studies of Dendrochilum (Barkman \& Simpson, 2001, 2002), which enabled us to use already existing databases of sequences. A phylogenetic approach for inferring the geographic origin of cultivated plant material has been used before, i.e. by Wanntorp et al. (2002).

1) Botanical Museum, Natural History Museum of Denmark, University of Copenhagen, Gothersgade 130, DK-1123 Copenhagen, Denmark.

2) Nationaal Herbarium Nederland, Universiteit Leiden branch, P.O. Box 9514, 2300 RA Leiden, The Netherlands.

3) Eka Karya Botanic Garden, Candi Kuning, Baturiti, Tabanan 82191, P.O. Box 3424, Denpasar 80034, Bali, Indonesia. 


\section{MATERIALS AND METHODS}

\section{DNA extractions and amplifications}

Total genomic DNA was extracted from $50 \mathrm{mg}$ of silica gel dried leaf material using DNeasy extraction kits and protocols of QIAGEN (Leusden, The Netherlands). PCR products of the $a c c D$-psaI intergenic spacer and nrITS1-5.8S-ITS2 regions of the three species here described were collected using the primers and PCR programs described in Barkman \& Simpson (2002). DNA sequences were obtained on an ABI 377 automated sequencer (Applied Biosystems) using the protocols described in Gravendeel et al. $(2001,2004)$ and submitted to the GenBank database under accession numbers AY534922-AY534927.

\section{Phylogenetic analyses}

The DNA sequences obtained for this study were added to the matrix compiled by Barkman \& Simpson (2002). Maximum parsimony analyses were performed with PAUP*4.0b10 (Swofford, 1999) using heuristic search, ten replicates of randomtaxon entry, and tree bisection reconnection (TBR) swapping. As outgroup, Pholidota clemensii Ames was used, just as in Barkman \& Simpson (2002). All characters were assessed as independent, unordered, and equally weighted. The relative robustness of clades found was assessed by performing 1000 replicates of bootstrapping (Felsenstein, 1995) using simple stepwise additions, subtree pruning and regrafting (SPR) swapping, MULTREES on, and holding only ten trees per replicate.

\section{Preparation of descriptions}

The morphological terminology applied in the species descriptions generally follows Stearn's (1983) vocabulary and list of individual absolute terms.

\section{RESULTS}

\section{Sequence divergence}

The accD-psaI alignment consisted of 894 positions and contained 16 phylogenetically informative substitutions and 13 indels (of which 7 were synapomorphic) varying in size between 5 and $25 \mathrm{bp}$. Mean pairwise distances within the ingroup were generally low and varied between 0 and $2.6 \%$.

The nrITS1-5.8S-ITS2 alignment consisted of 656 positions and contained 93 phylogenetically informative substitutions and 12 indels (of which 6 were synapomorphic) varying in size between 1 and $8 \mathrm{bp}$. Mean pairwise distances within the ingroup varied between 0 and $11.5 \%$.

\section{Phylogenetic analyses}

Maximum parsimony analysis of the nuclear sequences yielded 32 most parsimonious trees (MPTs; length 249 steps; $\mathrm{CI}=0.71 ; \mathrm{RI}=0.80$ ). The strict bootstrap consensus is shown in Fig. 1 (left-hand). Clades present in many of the separate MPTs consist of all Bornean (bootstrap support of 63\%) and Sumatran (bootstrap support of 82\%) species. Maximum parsimony analysis of the plastid sequences yielded $>10,000 \mathrm{MPTs}$ (length 66 steps; $\mathrm{CI}=0.99 ; \mathrm{RI}=0.98$ ). The strict bootstrap consensus is shown in Fig. 1 (right-hand). Clades retrieved in many of the separate MPTs consist of three subsets 

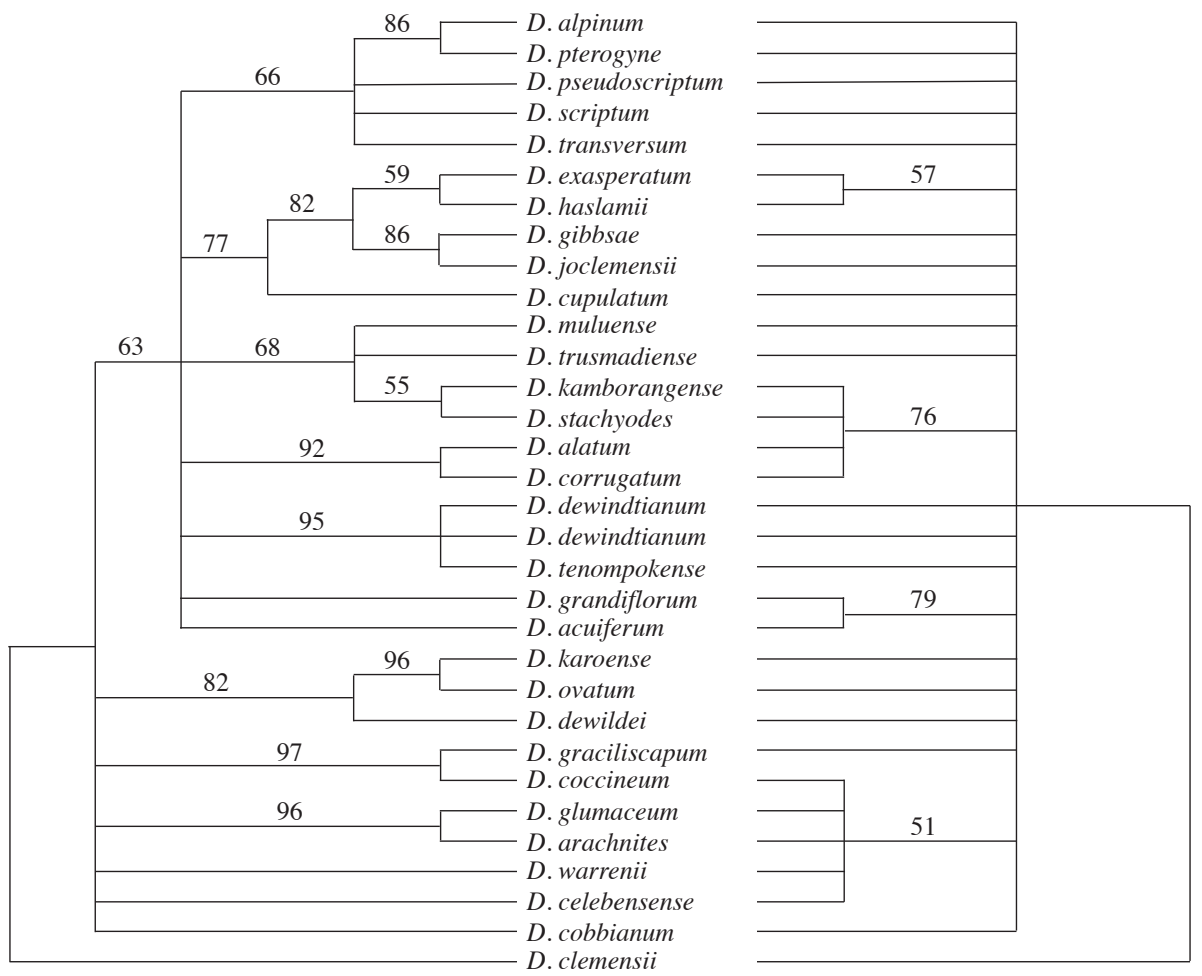

Fig. 1. Strict consensus trees of 32 MPTs from analyses of nrITS1-5.8S-ITS2 (left-hand) and > 10,000 MPTs from analyses of $a c c D$-psaI sequences (right-hand). Numbers above the branches indicate the bootstrap percentages.

of Bornean species (bootstrap support of 57\%, 76\% and 79\%, respectively) and part of the species of the Philippines and Sulawesi (bootstrap support of 51\%). Because of the presence of hybrids (Barkman \& Simpson, 2002) and the different set of species sampled for both data sets, we refrained from performing a total evidence analysis.

\section{DISCUSSION}

Separate phylogenetic analyses of the sequences of the accD-psaI intergenic spacer and nrITS1-5.8S-ITS2 regions indicate that Dendrochilum coccineum is most closely related to D. arachnites Rchb.f., D. celebesense, D. glumaceum Lindl., D. graciliscapum (Ames) Pfitzer, and D. warrenii and seems nested in 'the Philippine lineage' as described by Barkman \& Simpson (2001). Dendrochilum celebesense and D. warrenii seem most closely related to the species of the 'Philippine lineage' in the $a c c D$ - $p s a I$ tree and have a more isolated position in the nrITS1-5.8S-ITS2 tree (Fig. 1). Summarising, the molecular results obtained firmly corroborate a Philippine origin of $D$. coccineum. Based on the molecular results obtained, it seems equally likely that the specimen analysed of $D$. warrenii originally came from Sulawesi or the Philippines, although 
it is morphologically most similar to Philippine species of Dendrochilum. It must be stressed, however, that the geographic origin of species of unknown provenance can only be inferred successfully with a phylogenetic approach when genotypic variability is not too large.

The new species here described are all nested within clades of other members of Dendrochilum subgenus Platyclinis in the accD-psaI and nrITS1-5.8S-ITS2 trees and molecular characters, therefore seem to confirm their placement based on morphology. As only species of subgenus Platyclinis (Benth.) Pfitzer were sampled, however, and only single specimens were studied, sequencing of additional species and specimens from subgenera Acoridium (Nees \& Meyen) Pfitzer \& Kraenzl., Dendrochilum, and Pseudacoridium (Ames) Butzin ex H.A. Pedersen would be the only way to assign a subgeneric rank with certainty.

\section{SYSTEMATIC TREATMENT}

\section{Dendrochilum celebesense H.A. Pedersen \& Gravend., spec.nov. - Fig. 2}

D. tenuissimo Kraenzl. affine, sed bracteis rotundatis, floribus majoribus et sepalis petalisque lanceolate-oblongis distinguitur. - Typus: Gravendeel \& Mudiana 697 (holotypus L), Indonesia, Sulawesi, sine loco/cult. Kebun Raya Bali.

Relatively small, tufted, epiphytic herb. Roots appearing from the rhizome, thin. Pseudobulbs clustered on a short rhizome, fusiform, 3-4 cm long, c. $0.3 \mathrm{~cm}$ diam., 1-leaved, initially covered with c. 4 imperfectly tubular, acute to obtuse, setose cataphylls which soon disintegrate into persistent fibres. Leaf petiolate; petiole channelled, 7.7-8 cm long; blade dorsiventrally complanate, herbaceous with 7 distinct (and many indistinct) veins, linear-lanceolate, acute, entire, $22-23$ by $1 \mathrm{~cm}$. Inflorescence synanthous, racemose; peduncle erect and curved, very slender, terete, 20.3-22.7 cm long, finely and sparsely setose; rachis nodding to pendent with distichously alternating flowers, dense, manyflowered with internodes of c. $2 \mathrm{~mm}$, quadrangular in transverse section, furrowed, $10-18.5 \mathrm{~cm}$ long, subglabrous, basally with 3 or 4 appressed, non-floriferous bracts. Floral bracts persistent, glumaceous, broadly ovate when spread out, obtuse to rounded (sometimes minutely mucronate), $2.8-3.2$ by $2.9-3 \mathrm{~mm}$, entire to slightly irregular, somewhat scarious, many-veined, (sub)glabrous. Flower yellowish green. Sepals and petals spreading, (sub)glabrous, entire, 3-veined; dorsal sepal lanceolate-oblong, acuminate, $3.7-4.1$ by $1-1.2 \mathrm{~mm}$; lateral sepals obliquely lanceolate-oblong, acuminate, $3.8-4.2$ by $1.3-1.4 \mathrm{~mm}$; petals lanceolate-oblong, acuminate, $3.7-4$ by $1.2-1.3 \mathrm{~mm}$. Labellum firmly attached to the column, porrect, sessile, fleshy, hastate, acute, entire, slightly concave, $2.1-2.3$ by $1.8-1.9 \mathrm{~mm}$, indistinctly 3 -veined, glabrous and smooth, in its proximal half with two low, longitudinal lamellae, each ending in an acute, conical callus. Column stout, semiterete-clavate, straight, c. $1 \mathrm{~mm}$ long, smooth, distally prolonged and - especially - dilated into a rounded, quite entire apical wing which shortly but distinctly exceeds the anther; foot and stelidia absent. Anther transversely elliptic to broadly ovate-elliptic in upper view, lobed posteriorly, obtuse in front, with a conical wart on top. Pollinia four, subpyriform with diminutive caudicles. Rostellum somewhat protruding, flat, triangular; fertile stigma elliptic-oblong in outline, concave with somewhat elevated margins. Ovary (including pedicel) subterete, slightly incurved, 1.6-2 mm long, glabrous. Capsule not seen. 


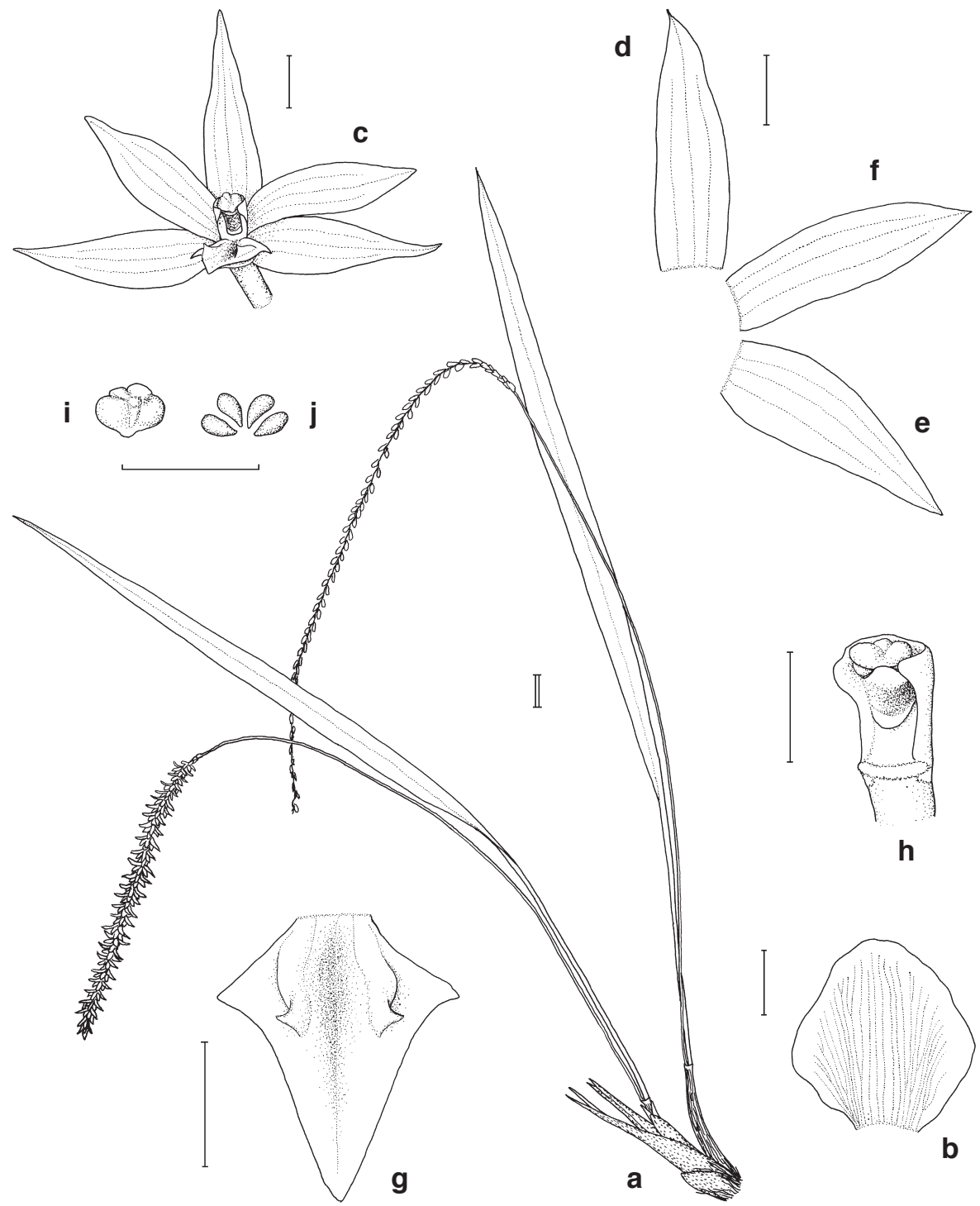

Fig. 2. Dendrochilum celebesense H.A. Pedersen \& Gravend. a. Habit; b. floral bract; d. flower; d. dorsal sepal; e. lateral sepal; f. petal; g. lip; h. column; i. anther; j. pollinia (Gravendeel \& Mudiana 697, L). Drawn by H.A. Pedersen. - Single-line scale $=1 \mathrm{~mm}$; double-line scale $=10 \mathrm{~mm}$.

Distribution - Sulawesi.

Notes -1 . This species belongs to the phenetically defined sect. Eurybrachium Carr ex J.J. Wood et al. (for sectional features, see Pedersen et al., 1997: 31, 32). Within this section, it seems close to D. tenuissimum Kraenzl., likewise from Sulawesi. Unfortunately, the type of $D$. tenuissimum has not been located and is generally considered to have been destroyed at B (Pedersen, 1995: 402; Pedersen et al., 1997: 40; Thomas 
\& Schuiteman, 2002: 29). However, comparing with information from the protologue of D. tenuissimum (Pfitzer \& Kränzlin, 1907: 98), D. celebesense seems to be clearly distinguished from the latter by its rounded bracts, its much larger flowers, and its lanceolate-oblong sepals and petals (in the protologue of D. tenuissimum, Kränzlin characterized the bracts as "brevi-acutatae", the sepals and petals as "e basi paulum latiore triangula" as well as "1,5 mm longi", and the labellum as "1 $\mathrm{mm}$ ").

2. The specific epithet records Sulawesi (Celebes), the island where the specimen, cultivated in Bali, was originally collected in the wild.

\section{Dendrochilum coccineum H.A. Pedersen \& Gravend., spec. nov. - Fig. 3}

D. convallariaeformi Schauer affine, sed foliis coriaceis, floribus coccineis, marginibus sepalorum petalorumque revolutis et labello tres carinas longas habenti distinguitur. - Typus: Warren EQ 3060 (holotypus C), sine loco et coll./cult. Richard C. Warren anno 2003.

Relatively small, tufted epiphytic herb. Roots appearing from the rhizome, moderately thick, branched. Pseudobulbs clustered on a short rhizome, obpyriform, 1.7-2.2 cm long, 0.7-1.1 cm diam., 1-leaved, initially covered with c. 3 imperfectly tubular, acute to obtuse, strongly setose cataphylls which soon disintegrate into persistent fibres. Leaf petiolate; petiole channelled, c. $4 \mathrm{~cm}$ long; blade dorsiventrally complanate, shiny dark green above, dull light green below, leathery with 3-7 at least on the lower surface distinct (and many indistinct) veins, lanceolate, obtuse, entire, c. 15.3 by c. $2.1 \mathrm{~cm}$, particularly on the lower surface furnished with numerous minute dark setae. Inflorescence synanthous, racemose; peduncle erect and curved, very slender, terete, c. $14.8 \mathrm{~cm}$ long, finely setose; rachis nodding with distichously alternating flowers (but the rachis axis twisted so as to produce a terete rachis), dense, many-flowered with internodes of $1.5-2 \mathrm{~mm}$, quadrangular in transverse section, furrowed, c. $5.3 \mathrm{~cm}$ long, finely setose, basally with c. 4 appressed, non-floriferous bracts. Floral bracts persistent, glumaceous, broadly ovate-triangular to almost hemicircular when spread out, rounded to subacute, $3.1-4.2$ by $3.7-3.9 \mathrm{~mm}$, entire, somewhat scarious, manyveined, finely setose. Flower deep crimson. Sepals and petals somewhat spreading, entire with revolute margins, glabrous, 3-veined; dorsal sepal linear-oblong, rounded to obtuse, $5.9-6.4$ by $1.8-2 \mathrm{~mm}$; lateral sepals obliquely oblong, obtuse to rounded (sometimes minutely mucronate), $6-6.5$ by $2.2-2.3 \mathrm{~mm}$; petals oblanceolate-oblong, obtuse, $5.5-6.5$ by $2.2-2.3 \mathrm{~mm}$. Labellum firmly attached to the column, porrect, sessile, somewhat fleshy, elliptic-oblong with proximally incurved margins, (sub)acuminate, entire, $5.4-5.6$ by $2.4-2.7 \mathrm{~mm}, 3$-veined, glabrous and smooth, provided with two lateral keels running from near the base to near the apex of the labellum (tapering above the middle) and with a much smaller (often indistinct) median keel running from the middle to the apex of the labellum. Column stout, semiterete, straight, c. $1.8 \mathrm{~mm}$ long, smooth, distally prolonged into a bidentate apical wing (sometimes with an apiculum in the sinus) which distinctly exceeds the anther; foot absent; stelidia two, appearing from the middle or distal part of the column proper, erect, (narrowly) triangular, sometimes slightly falcate, obtuse to subacute, equalling the column proper, smooth. Anther suborbicular in upper view, lobed posteriorly, truncate in front, with a high, conical wart on top. Pollinia four, more or less clavate with relatively long caudicles. Rostellum somewhat protruding, flat, triangular; fertile stigma hemicircular to triangular in 


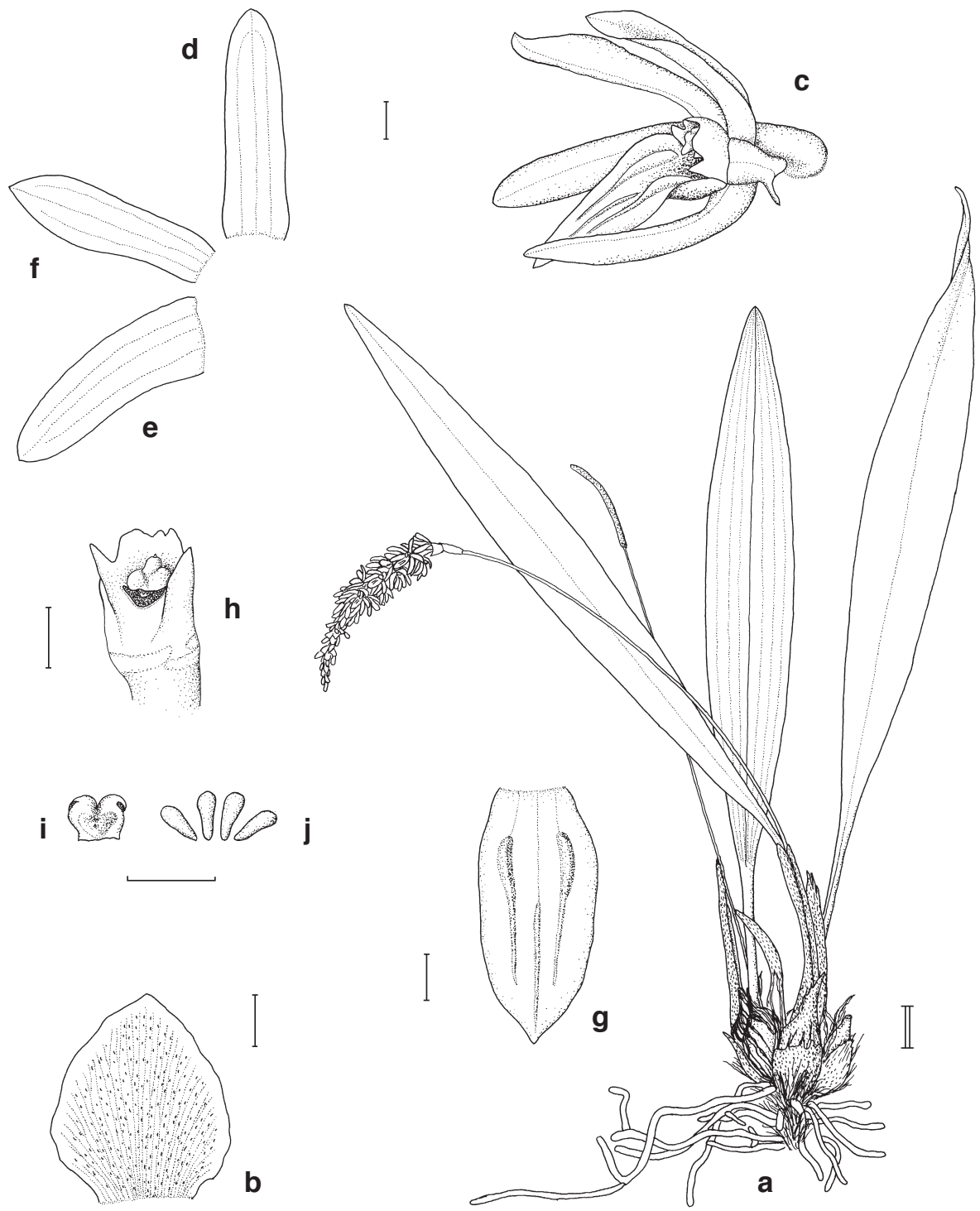

Fig. 3. Dendrochilum coccineum H.A. Pedersen \& Gravend. a. Habit; b. floral bract; c. flower; d. dorsal sepal; e. lateral sepal; f. petal; g. lip; h. column; i. anther; j. pollinia (Warren EQ 3060, C). Drawn by H.A. Pedersen. - Single-line scale $=1 \mathrm{~mm}$; double-line scale $=10 \mathrm{~mm}$.

outline, concave with slightly elevated margins. Ovary (including pedicel) semiterete, somewhat incurved, c. $2 \mathrm{~mm}$ long, glabrous. Capsule not seen.

Distribution - Unknown.

Notes -1 . This species belongs in the phenetically defined sect. Eurybrachium (for sectional features, see Pedersen et al. 1997: 31,32). Within this section it seems referable to a presumably natural group of Philippine endemics that also includes $D$. con- 
vallariaeforme, D. propinquum Ames, and D. ecallosum Ames (cf. Pedersen 1997a: 131) - none of which are included in the phylogenetic analysis above. Dendrochilum coccineum is particularly similar to $D$. convallariaeforme but differs from the latter species primarily by its leathery leaves and deep crimson flowers, the revolute margins of its sepals and petals, and the three long keels of its labellum. According to the nrITS sequence tree, D. coccineum is closely related to D. graciliscapum (Ames) Pfitzer, which is endemic to the Philippines and has a similarly shaped column and labellum.

2. The specific epithet is derived from the Latin coccineus, deep red, referring to the deep crimson flowers.

\section{Dendrochilum warrenii H.A. Pedersen \& Gravend., spec. nov. - Fig. 4}

D. flexuoso H.A. Pedersen affine, sed foliis longioribus angustioribus, petalis linearelanceolatis acutis, labello longiore, quod infra medium latissimo est, columna breviore et brachiis basalibus lateralibus columnae antheram distincte superantibus distinguitur. - Typus: Warren EQ 3066 (holotypus C), sine loco et coll./cult. Richard C. Warren anno 2003.

Small, tufted, epiphytic herb. Roots appearing from the rhizome, thin, unbranched. Pseudobulbs clustered on a short rhizome, fusiform, 1.7-1.9 cm long, c. $0.4 \mathrm{~cm}$ diam., 1-leaved, initially covered with 3 or 4 tubular, acute to acuminate, setose cataphylls which soon disintegrate into persistent fibres. Leaf petiolate; petiole distinctly channelled, $0.8-1.1 \mathrm{~cm}$ long; blade dorsiventrally complanate, leathery, narrowly linear, acute, entire, $9.5-10.5$ by $0.1 \mathrm{~cm}$. Inflorescence synanthous, racemose; peduncle erect and curved, very slender, terete, $7.2-8.4 \mathrm{~cm}$ long, finely and sparsely setose; rachis nodding to pendent with distichously alternating flowers, dense, 10-12-flowered with internodes of c. $2 \mathrm{~mm}$, quadrangular in transverse section, slightly furrowed, 2.8-2.9 $\mathrm{cm}$ long, glabrous, basally with 4 or 5 appressed, non-floriferous bracts. Floral bracts persistent, glumaceous, lanceolate-elliptic when spread out, acuminate, 4.4-4.8 by 1.7-2.1 mm, entire, somewhat scarious, many-veined, finely and sparsely setose. Flower white. Sepals and petals somewhat spreading, glabrous, 3-veined; dorsal sepal linear, acute, $5.9-6.1$ by $0.9-1 \mathrm{~mm}$, entire; lateral sepals linear, acuminate, $6.3-6.7$ by 2.9-3 mm, entire; petals linear-lanceolate, acute, $4.4-4.6$ by $0.8-1.1 \mathrm{~mm}$, finely erose. Labellum easily versatile, porrect with a knee-like bend at its base, sessile, lanceolate with upcurved, finely erose margins, acute to acuminate, $2-2.2$ by $0.9 \mathrm{~mm}, 3$-veined, glabrous and smooth, provided with two lateral and a smaller median keel running almost from the base to the apex of the labellum. Column relatively slender, subclavate, slightly incurved, 1.1-1.2 mm long, smooth, distally prolonged into a bidentate wing that exceeds the anther; foot short; stelidia two, basal, erect, linear, obtuse, equalling the column proper, smooth. Anther suborbicular in upper view, lobed posteriorly, rounded in front, with a high, conical wart on top. Pollinia four, subpyriform with diminutive caudicles. Rostellum somewhat protruding, flat, triangular; fertile stigma elliptic-oblong in outline, concave with slightly elevated margins. Ovary (including pedicel) semiterete, slightly incurved, 2.1-2.2 mm long, glabrous. Capsule not seen.

Distribution - Unknown.

Notes -1 . This species belongs to the phenetically defined sect. Platyclinis (for sectional features, see Pedersen et al. 1997: 42). Morphologically, it seems closest to 


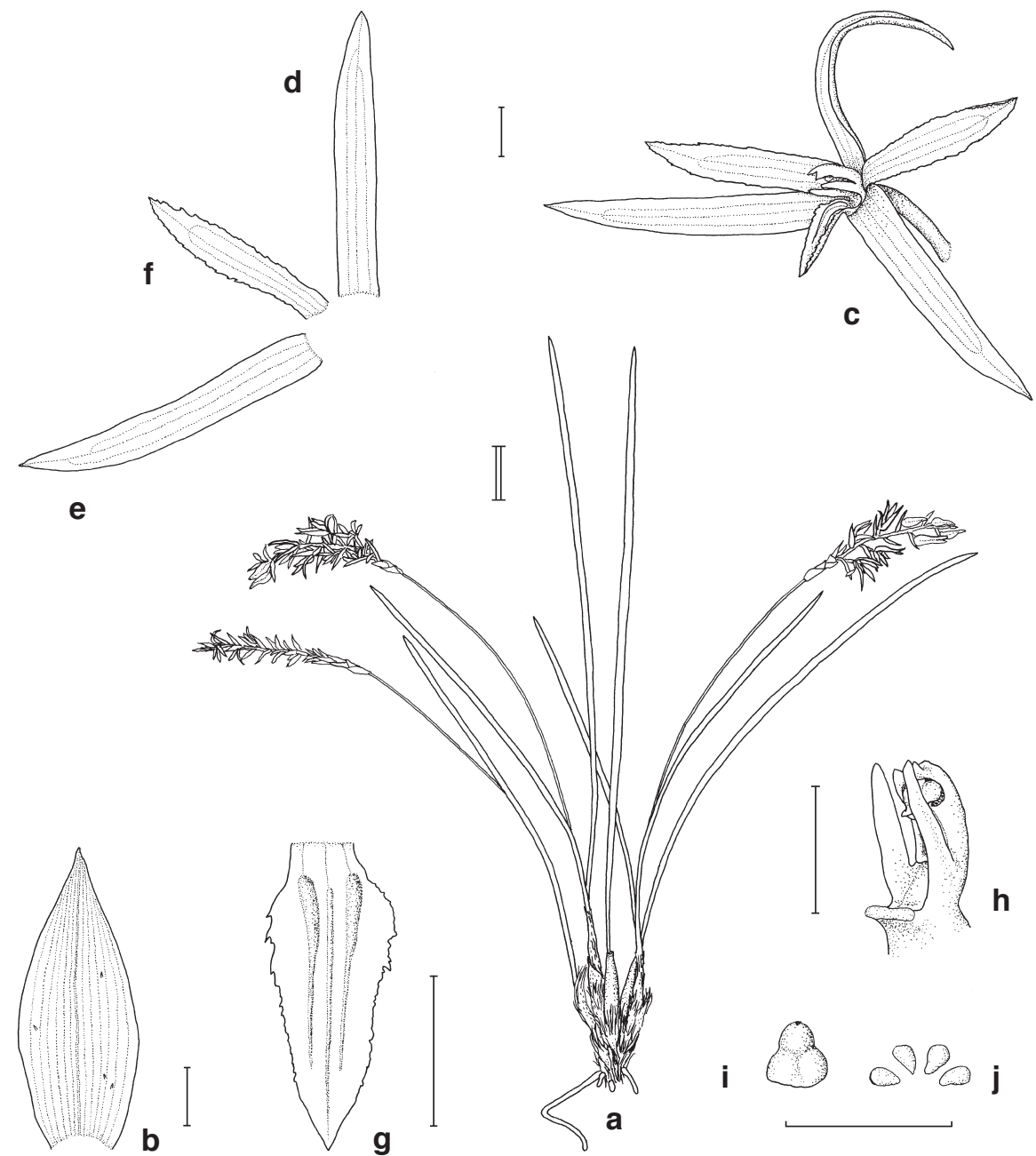

Fig. 4. Dendrochilum warrenii H.A. Pedersen \& Gravend. a. Habit; b. floral bract; c. flower; d. dorsal sepal; e. lateral sepal; f. petal; g. lip; h. column; i. anther; j. pollinia (Warren EQ 3066, C). Drawn by H.A. Pedersen. - Single-line scale $=1 \mathrm{~mm}$; double-line scale $=10 \mathrm{~mm}$.

the Philippine D. flexuosum H.A. Pedersen. It differs from the latter by its longer and narrower leaves, its linear-lanceolate, acute petals, its longer labellum which is widest below the middle, and its basal stelidia that are subequal to the column proper.

2. In March 2003, a live specimen of $D$. warrenii was exhibited by Blair Sibun at the European Orchid Conference in London under the horticultural name Dendrochilum sp. 'Sherborne Star' (submitted as D. pictum, nom. nud.) - for a colour photograph, see Hermans \& Hermans (2003: 209, centre right). Incidentally, the specimen received an RHS Certificate of Cultural Commendation.

3. The specific epithet honours Richard C. Warren who provided us with the material from which the type specimen was prepared. 


\section{ACKNOWLEDGEMENTS}

We wish to express our grateful thanks to Richard C. Warren for providing us with material of Dendrochilum warrenii and D. coccineum and Dedy Darnaedi for providing us with material of $D$. celebesense and allowing us to describe these new species from their collections. The ASEAN Regional Centre for Biodiversity Conservation (ARCBC, Los Baños) is gratefully acknowledged for funding travel costs of BG. Thanks are also due to the Eka Karya Botanic Garden Bali for providing facilities and hospitality and Todd Barkman and an anonymous reviewer for suggestions which greatly improved the manuscript.

\section{REFERENCES}

Barkman, T.J. \& B.B. Simpson. 2001. Origin of high-elevation Dendrochilum species (Orchidaceae) endemic to Mount Kinabalu, Sabah, Malaysia. Syst. Bot. 26: 658-669.

Barkman, T.J. \& B.B. Simpson. 2002. Hybrid origin and parentage of Dendrochilum acuiferum (Orchidaceae) inferred in a phylogenetic context using nuclear and plastid DNA sequence data. Syst. Bot. 27: 209-220.

Comber, J.B. 2001. Orchids of Sumatra. Royal Botanic Gardens, Kew.

Felsenstein, J. 1995. Confidence limits on phylogenies: an approach using the bootstrap. Evolution 39: 783-791.

Gravendeel, B., M.W. Chase, E.F. de Vogel, M.C. Roos, T.H.M. Mes \& K. Bachmann. 2001. Molecular phylogeny of Coelogyne (Epidendroideae, Orchidaceae) based on plastid RFLPs, matK, and nuclear ribosomal ITS sequences: evidence for polyphyly. Amer. J. Bot. 88: 1915-1927.

Gravendeel, B., M.C.M. Eurlings, C. van den Berg \& P.J. Cribb. 2004. Phylogeny of Pleione (Orchidaceae) and parentage analysis of its wild hybrids based on plastid and nuclear ribosomal ITS sequences and morphological data. Syst. Bot. 29: 50-63.

Hermans, C. \& J. Hermans. 2003. RHS awards 13 March 2003 at the European Orchid Conference. Orchid Rev. 111: 200-209.

Pedersen, H.A. 1995. Thirteen new species of Dendrochilum (Orchidaceae), a new record from Burma, and a checklist of the genus in East Malesia. Nordic J. Bot. 15: 381-402.

Pedersen, H.A. 1997a. The genus Dendrochilum (Orchidaceae) in the Philippines - a taxonomic revision. Opera Bot. 131: 1-205.

Pedersen, H.A. 1997b. Dendrochilum cootesii, a new protandrous species from the Philippines. Lindleyana 12: 205-207.

Pedersen, H.A. 2001. One new and one rediscovered species of Dendrochilum (Orchidaceae) from the Philippines. Lindleyana 16: 231-234.

Pedersen, H.A., J.J. Wood \& J.B. Comber. 1997. A revised subdivision and bibliographical survey of Dendrochilum (Orchidaceae). Opera Bot. 130: 1-85.

Pfitzer, E. \& F. Kränzlin. 1907. Orchidaceae-Monandrae-Coelogyninae. In: H.G.A. Engler (ed.), Das Pflanzenreich. Regni vegetabilis conspectus, IV 50 II B 7. Engelmann, Leipzig.

Stearn, W.T. 1983. Botanical Latin. History, grammar, syntax, terminology and vocabulary. 3rd ed. David \& Charles, Newton Abbot.

Swofford, D.L. 1999. PAUP*: phylogenetic analysis using parsimony, version 4.0. Champaign: Illinois Natural History Survey.

Thomas, S. \& A. Schuiteman. 2002. Orchids of Sulawesi and Maluku: a preliminary catalogue. Lindleyana 17: 1-72.

Wanntorp, L., H.E. Wanntorp \& M. Kallersjo. 2002. The identity of Gunnera manicata Linden ex Andre - resolving a Brazilian-Colombian enigma. Taxon 51: 493-497.

Wood, J. J. 2001. Dendrochilum of Borneo. Natural History Publications (Borneo), Kota Kinabalu \& Royal Botanic Gardens, Kew. 